Poznańskie Studia Teologiczne 29(2015), s. 249-264.

doi: $10.14746 /$ pst.2015.29.15

Karol Wielgosz ${ }^{1}$

Uniwersytet Śląski w Katowicach

Wydział Teologiczny

\title{
Hermeneutyka pojęcia evangelical w Evangelical Catholicism George'a Weigla
}

W swojej książce Boży wybór ${ }^{2}$ George Weigel przytoczył kilka charakterystycznych wypowiedzi publicystów dotyczących wyboru Josepha Ratzingera na Stolicę Piotrową. Zwrócił uwagę na jedną z nich: niespodziewaną, a jakże znaczącą. Otóż, Timothy George, uznany ewangelikalny akademik, na łamach ewangelikalnego periodyku „Christianity Today” napisał, że Benedykt XVI może być „Zwiastunem nowej reformacji” i że w każdym wypadku ,jego pontyfikat będzie jednym z wielkich momentów dla Kościoła chrześcijańskiego, zwłaszcza dla ewangelików"3. To śmiałe twierdzenie cytowany przez Weigla autor uzasadnił przypomnieniem ważnych rysów twórczości Ratzingera, który „poważnie traktuje prawdę”, a ,jego teologia skupiona jest na Biblii”, natomiast „przesłanie jest skoncentrowane na Chrystusie”. Co więcej, według tego teologa, Ratzinger „prezentuje augustiański punkt widzenia” i „opowiada się za kulturą życia”. Profesor George, co skrupulatnie i życzliwie zauważa Weigel, poszedł dalej w swojej analizie, pisząc: „Te dwa tematy - odnowa Kościoła poprzez uwielbienie Boga i ewangelizacja świata poprzez potęgę Pisma Świętego - mogą trwale wyznaczyć spuściznę tego obecnego pontyfikatu: nowy benedyktyński moment $\mathrm{w}$ historii Kościoła"4. Oto ewangelikalny teolog ocenia twórczość prefekta Kongregacji Nauki Wiary jako broniącą wartości teologii protestanckiej i, co więcej, mogącą być zaczynem przełomowego, wręcz reformacyjnego momentu w historii Kościoła.

Ta opinia Timothy'ego George'a, tak skrupulatnie odnotowana przez George Weigla, znakomicie przedstawia bogactwo i złożoność pojęcia evangelical klu-

\footnotetext{
${ }^{1}$ Karol Wielgosz OP - urodzony w 1979 r., dominikanin, katecheta, student w Katedrze Teologii Dogmatycznej i Duchowości Wydziału Teologicznego Uniwersytetu Śląskiego. Adres do korespondencji: karol.wielgosz@dominikanie.pl

${ }^{2}$ G. Weigel, Boży wybór, Kraków 2006.

${ }^{3}$ T. George, The Promise of Benedict XVI, w: Christianity Today, June 2005, za: G. Weigel, Boży wybór, dz. cyt., s. 208.

${ }^{4}$ G. Weigel, Boży wybór, dz. cyt., s. 208.
} 
czowego dla zrozumienia propozycji reformy życia Kościoła, którą przedstawił w znakomitej książce: Evangelical Catholicism: Deep Reform in the 21st-Century Church ${ }^{5}$. Książka ta została przetłumaczona na wiele języków. Była i jest szeroko dyskutowana zarówno przez zawodowych teologów, jak i zwyczajnych ludzi, przez katolików i przez członków innych wspólnot chrześcijańskich, i to na całym świecie (w różnych kontekstach kulturowych). Wydaje się więc, że warto dokonać analizy wielowymiarowego pojęcia evangelical oddanego w polskim tłumaczeniu przymiotnikiem: 'ewangeliczny', tym bardziej że w ten sposób będziemy mogli lepiej zrozumieć ciekawą propozycję wpływowego katolickiego pisarza.

Niniejsze studium nie ma bowiem na celu badania tego, co zostało utracone albo odkryte (lub chociażby: uwypuklone) w thumaczeniu - nie ma on być lingwistyczną analizą. Celem niniejszej pracy jest lepsze zrozumienie wizji katolicyzmu nowej ewangelizacji, która została zaproponowana przez George’a Weigla, przez pryzmat różnych znaczeń słowa evangelical. To zaś pozwoli na nazwanie źródeł tej koncepcji, jej teologicznych kontekstów i perspektyw, jakie przed nami otwiera. Analiza ta stawia sobie także pewne cele ekumeniczne, pomoże bowiem określić, co wspólnego ma wizja katolicyzmu XXI wieku z ideałami współczesnego radykalnego protestantyzmu.

Aby tego dokonać, w pierwszej części tego eseju zostaną przedstawione leksykalne znaczenia angielskiego terminu evangelical i jego polskich odpowiedników. Kolejny rozdział, będący prezentacją głównych założeń koncepcji George'a Weigla, będzie poszukiwaniem odpowiedzi na pytanie, czy ta idea może być opisana słowem e w a n g e li c z n y. W trzeciej części natomiast zbadana zostanie możliwość określenia wizji popularnego pisarza jako e wangelikalnej bądź ewangelijnej.

\section{Evangelical - znaczenie słowa}

Słowo evangelical pojawia się nie tylko w tytule dzieła George'a Weigla. Wielokrotnie, bo aż 765 razy jest użyte na kartach tej książki. Kilkukrotnie występuje też $\mathrm{w}$ innych formach: evangelically i evangelism, najczęściej jako określenie katolicyzmu, ale także jako papiestwa, seminarium duchownego i innych rzeczywistości.

Według Oxford Dictionary of English przymiotnik evangelical oznacza rzecz, stan lub ideę, która odnosi się do Ewangelii; jest na niej ufundowana albo też na niej wzorowana. Rzecz można określić jako evangelical także wtedy, gdy jest ona

${ }^{5}$ G. Weigel, Evangelical Catholicism: Deep Reform in the 21 st-Century Church, [New York] 2014, thum. pol.: Katolicyzm ewangeliczny. Gruntowna reforma Kościoła w XXI wieku, Kraków 2014. W niniejszym opracowaniu będziemy się odwoływać do polskiego thumaczenia dzieła G. Weigla. 
związana z religią chrześcijańską lub też odnosi się do tej tradycji w ramach chrześcijaństwa protestanckiego, która podkreśla autorytet Biblii, osobistego nawrócenia i doktrynę zbawienia przez wiarę w nawrócenie ${ }^{6}$. Tę samą definicję zawiera także The New Oxford American Dictionary ${ }^{7}$.

Angielski termin evangelical ma więc wiele znaczeń i, co się z tym wiąże, nie ma swojego odpowiednika w języku polskim. Angielskie evangelical można przetłumaczyć bowiem, po pierwsze, jako nazwę: 'ewangelik'. Można też oddać znaczenie tego słowa przymiotnikami, takimi jak: 'ewangeliczny' bądź 'ewangelijny', a także 'ewangelicki', a nawet 'żarliwy'8. Jakie treści kryją się za tymi słowami?

Wielki słownik języka polskiego wyjaśnia, że ewangelik to osoba wyznająca ewangelicyzm, który z kolei jest po prostu ogółem doktryn powstałych w wyniku reformacji. Słownik ten nie zawiera definicji słów ewangelijny, ewangeliczny czy też ewangelikalny9. Podobnie Elektroniczna encyklopedia $i$ stownik ortograficzny $P W N$ zawiera jedynie wytłumaczenie słowa ewangelik (które jest identyczne z tym, które można odnaleźć w wyżej wymienionym słowniku) i także nie tłumaczy innych interesujących nas terminów ${ }^{10}$.

W celu lepszego zrozumienia rozpatrywanych słów warto odwołać się do tego, jak one są rozumiane przez tych, którzy utożsamiają się z ewangelikalizmem. Strona internetowa Ewangelikalnej Wyższej Szkoły Teologicznej zawiera takie oto rozróżnienie znaczeń wyżej wymienionych terminów:

W języku polskim występują trzy derywaty przymiotnikowe (poza rzadszym „ewangelijny") greckiego pojęcia Ewangelia (euangelion): ewangelicki, ewangeliczny $i$ ewangelikalny. Pierwszy, którego rzeczownikowym odpowiednikiem jest ewangelicyzm, używają kościoły powstałe podczas szesnastowiecznej reformacji [...]. Drugim terminem określane są kościoły protestanckie, wywodzące się z tzw. nurtu drugiej reformacji, szczególnie wyróżniające się praktykowaniem chrztu dorosłych (np. Kościół Ewangelicznych Chrześcijan, Kościół Chrześcijan Baptystów, Ewangeliczna Wspólnota Zielonoświątkowa i inne) lub organizacje zrzeszające te kościoły (np. Alians Ewangeliczny). Trzeci termin - ewangelikalny - jest zasadniczo synonimem pojęcia ewangeliczny; obydwa są thumaczeniami jednego terminu angielskiego evan-

6 "Evangelical: adjective: of or according to the teaching of the gospel or the Christian religion; Of or denoting a tradition within Protestant Christianity emphasizing the authority of the Bible, personal conversion, and the doctrine of salvation by faith in the Atonement; Zealous in advocating or supporting a particular cause. Noun: a member of the evangelical tradition in the Christian Church", w: Oxford Dictionary of English, [Kindle edition] 2010.

${ }^{7}$ The New Oxford American Dictionary, [Kindle edition] $2008^{2}$.

${ }^{8}$ [E]vangelical I n ewangelik m, -czka f; II adj 1 Relig (referring to gospel) ewangeliczny; ewangelijny 2 Relig (Protestant) ewangelicki; 3 fig (zealous) żarliwy, w: Wielki stownik angielsko-polski, Warszawa 2004.

${ }^{9}$ Wielki stownik języka polskiego, http://wsjp.pl/ [dostęp: 28.04.2005].

${ }^{10}$ Elektroniczna encyklopedia $i$ stownik ortograficzny PWN, Warszawa 2002. 
gelical. Derywat ewangelikalny oraz jego rzeczownikowy ekwiwalent ewangelikalizm ma jednak również swoje odrębne konotacje, odnosi się do ogólnoświatowego ruchu międzywyznaniowego reprezentowanego w Polsce m.in. przez Unię Ewangelikalną ${ }^{11}$.

Z przytoczonego tutaj cytatu wynika, że aby zrozumieć znaczenie słowa ewangelikalny, trzeba poznać podstawowe założenia, zasady i wartości ewangelikalizmu. O ile bowiem łatwo możemy przyjąć, że polskie słowo ewangeliczny określa nie tylko Kościoły powstałe w wyniku tak zwanej drugiej reformacji, ale każdą rzecz, stan lub ideę wynikającą z Ewangelii lub mającą cechy Ewangelii, o tyle trudniejsze jest precyzyjne wyznaczenie pól znaczeniowych pojęć: ewangelicki, ewangelijny i ewangelikalny.

Próbując wyjaśnić te słowa, autorzy przytoczonej wypowiedzi odnoszą się do różnic i podobieństw, które występują między Kościołami i wspólnotami chrześcijańskimi tak zwanej pierwszej i drugiej reformacji. Tłumacząc termin ewangelikalny, odwołują się do ruchu chrześcijańskiego reprezentowanego przez Unię Ewangelikalną, ewangelikalna jest więc rzecz, idea, stan, która reprezentuje fundamentalne wartości i przekonania tych, którzy należą do tego ruchu. Jakie są więc podstawy ewangelikalizmu? Czym on jest?

Jest on ponadwyznaniowym nurtem w chrześcijaństwie - obecnym przede wszystkim we wspólnotach protestanckich, ale i w pewnym wymiarze istniejącym w Kościele katolickim - wywodzącym się z religijności pietystycznej i konserwatywnych ruchów ortodoksji protestanckiej, który podkreśla znaczenie osobistej relacji z Jezusem Chrystusem, rozstrzygającego autorytetu Pisma Świętego, konieczność nawrócenia, nowego narodzenia z Ducha Świętego, a także obowiązek głoszenia Ewangelii ${ }^{12}$. Te priorytety oczywiście są zakorzenione

\footnotetext{
${ }^{11} \mathrm{http} / / /$ www.ewst.pl/centrum-edukacyjne/ewangelikalizm/ [dostęp: 28.04.2015].

12 „Ewangelikalizm jako ruch międzywyznaniowy zrodził się w łonie konserwatywnego protestantyzmu na początku XX wieku. [...] Na Zachodzie jest prężnie rozwijającym się ruchem (np. World Evangelical Alliance), powszechnie uznanym przez chrześcijańskie środowiska, jak i władze świeckie. [...] Ewangelikalizm (teologia ewangelikalna stanowi jego egzemplifikację) wyznaje pierwsze symbole chrześcijańskie (np. Apostolskie Wyznanie Wiary, Nicejsko-Konstantynopolitańskie Wyznanie Wiary), akcentuje podstawowe tezy reformacyjne (Tylko Pismo, Tylko Chrystus, Tylko łaska, Tylko przez wiarę), traktując jednocześnie inne problemy dogmatyczne (w odróżnieniu m.in. od fundamentalizmu) jako drugorzędne. Ewangelikalizm podkreśla konieczność osobistej relacji człowieka z Bogiem przez Chrystusa, wyrażającej się w odpowiedniej postawie etycznej; zachęca do lektury Pisma Świętego, modlitwy i wpływu na społeczeństwo poprzez zaangażowanie misyjne, społeczne i naukowe. Interkonfesyjność ewangelikalna (jego przedstawiciele obecni są we wszystkich Kościołach protestanckich, jak i w Kościele Rzymskokatolickim) pozwala wykraczać ponad wiele spornych kwestii chrześcijańskich. Wyznawcy ewangelikalizmu mają różne zapatrywania eklezjologiczne (wyłączające jednak tzw. sukcesję apostolska), sakramentologiczne (za wyjątkiem sakramentalnego odrodzenia i transsubstancjacji), pneumatologiczne, ekumeniczne i inne"; za: http://www.ewst.pl/centrum-edukacyjne/ewangelikalizm/ [dostęp: 28.04.2015]. Por. także: Evangelicalism, w: R. Balmer, Encyclopedia of Evangelicalism, Waco 2004, s. 244-248; oraz
} 
w podstawach konserwatywnie interpretowanej nauki protestanckiej. $\mathrm{Ci}$, którzy zaliczają siebie do nurtu ewangelikalnego, przyjmują absolutną suwerenność Boga, fakt, że Biblia jest autorytatywnym zapisem Jego objawienia się, który może być właściwie odczytany tylko dzięki obecności Ducha Świętego, a także to, że ludzka natura jest całkowicie zepsuta, dlatego zbawienie jest efektem działania niczym niezasłużonej, autonomicznej łaski Bożej ${ }^{13}$. Ewangelikalną zatem jest idea lub też rzecz, która reprezentuje wyżej wymienione paradygmaty ewangelizmu.

Konkludując: angielski termin evangelical możne być oddany kilkoma polskimi słowami. Zakresy znaczeniowe tych słów są nieostre. Nie są także sformalizowane i, co więcej, choć są rozłączne - przenikają się. Evangelical thumaczone jako 'ewangeliczny' oznacza 'rzecz wynikająca z Ewangelii i na niej wzorowaną'. Evangelical rozumiane jako 'ewangelikalny' określa rzecz zgodną z podstawami 'ewangelizmu'. Słowa te mogą być też traktowane jako synonimy. Evangelical może być też tłumaczony jako 'ewangelicki' (zgodny z ideałami reformacji), 'ewangelijny' bądź po prostu 'żarliwy' - te pojęcia nie są jednak interesujące dla naszych rozważań. Zbadajmy zatem jak George Weigel używa pojęcia evangelical. Czym charakteryzuje się proponowany przez niego Evangelical Catholicism?

\section{Ewangeliczność katolicyzmu}

Przed sformułowaniem czym jest katolicyzm ewangeliczny George Weigel, określa, czym on nie jest. Czyni to już we wstępie do swojej książki. W lakoniczny wręcz sposób rozprawia się z opartymi na stereotypach oczekiwaniami dotyczącymi jego propozycji.

I tak, katolicyzm ewangeliczny nie jest, po pierwsze, bezkrytyczną adaptacją metod i praktyk liturgicznych i katechetycznych, które zostały wypracowane i rozwinięte na gruncie pentakostalnego protestantyzmu. Nie jest to też wizja katolicyzmu zgodna z popularnymi oczekiwaniami grup katolików określających się jako postępowi lub, wręcz przeciwnie, tradycjonalistyczni - innymi słowy: nie jest to program żadnej grupy ani ruchu kościelnego. Katolicyzm ewangeliczny to nie aplikacja amerykańskich zwyczajów kościelnych w innych kontekstach kulturowych; również nie jest to jedynie tymczasowa i pragmatyczna odpowiedź na brak zaufania wobec Kościoła spowodowany skandalami pedofilskimi. Wreszcie, nie jest to także wizja Kościoła alternatywnego, jakiegoś substytutu Kościoła łacińskiego dostosowana do realiów XXI wieku ${ }^{14}$. Katolicyzm ewangeliczny

A. McGrath, Evangelicalism and the Future of Christianity, London-Sydney 1994, s. 51; T. Zielinski, Protestantyzm ewangelikalny. Studium specyfiki religijnej, Katowice 2014, s. 39-64, 99.

${ }^{13}$ Por. Evangelicalism, w: Evangelical Dictionary of Theology, ed. W.A. Elwell, Grand Rapids 2001, s. 405-409.

${ }^{14}$ G. Weigel, Katolicyzm ewangeliczny, dz. cyt., s. 18n. 
to coś więcej ... To propozycja dużo głębiej idącej, duchowej reformy Kościoła ... To wizja poważnego i świadomego przeżywania chrześcijaństwa w ramach tradycji katolickiej.

Stosunkowo łatwo jest określić, czym nie jest katolicyzm ewangeliczny, dużo trudniej jest uchwycić istotę tak złożonego zjawiska. Toteż i sam Weigel przedkłada opisanie swojej wizji katolicyzmu XXI wieku nad sformułowanie jego lakonicznej definicji.

Swoje rozważania rozpoczyna od przypomnienia najważniejszego wydarzenia w katolickim świecie XX wieku - Soboru Watykańskiego II, który rozpoczął albo, wyrażając się ściślej, zintensyfikował reformowanie współczesnego katolicyzmu. Jedynie „zintensyfikował” - bowiem początku współczesnych prób odnowy Kościoła upatruje Weigel w pontyfikacie Leona XIII, który „w czasie swojego trwającego ponad ćwierć wieku panowania [...] spokojnie i wytrwale tworzył warunki umożliwiające nowe zaangażowanie katolicyzmu we współczesne życie kulturalne, polityczne, ekonomiczne i społeczne"15. Reformy filozofii, teologii i biblistyki dokonane przez tego papieża, a także (może nawet: nade wszystko) jego nowatorskie podejście do spraw społecznych przetarły szlaki propozycjom soborowym, stały się też dla nich swego rodzaju modelem (co Weigel wielokrotnie podkreśla na łamach swojej książki) ${ }^{16}$.

Sobór Watykański II - według Weigla - może być uważany za początek „Kościoła nowej ewangelizacji”, nową formę „skoncentrowania się Kościoła na Chrystusie i Misji"'17 i dlatego można uznać jego nauczanie za źródłowe dla katolicyzmu ewangelicznego. Wywodzi się on $\mathrm{z}$ tego samego pragnienia ludzi (i Boga), którzy Sobór przygotowali, zwołali i tworzyli - którzy pragnęli, aby katolicyzm był autentycznym świadectwem żywego Boga w XXI wieku. Z tego też powodu Weiglowska wizja katolicyzmu jest próbą zrealizowania dokumentów soborowych. „A intencją Soboru było - pisze Weigel - umieścić w centrum życia chrześcijańskiego Dobrą Nowinę i, wychodząc z tego centrum, zacząc budować zreformowany katolicyzm; katolicyzm ewangeliczny, zdolny zaproponować Dobrą Nowinę o Jezusie Chrystusie odczarowanemu światu"18.

To, co odróżnia reformę katolicyzmu proponowaną przez Weigla od wielu innych, które powstały (i powstaja) po Drugim Soborze Watykańskim, jest fakt, że próbuje ona przekroczyć wszelkie podziały dotyczące pożądanego kształtu

${ }^{15}$ Tamże, s. 30.

${ }^{16}$ „Jeśli za punkt wyjścia do zrozumienia głębszych nurtów w katolicyzmie, dochodzących do głosu pod koniec dwudziestego i na początku wieku dwudziestego pierwszego, przyjmiemy Leona XIII, [...] wówczas dopiero będziemy mogli zrozumieć właściwie Drugi Sobór Watykański i to, co zdarzyło się od tamtej pory - zrozumieć dogłębnie. Drugi Sobór Watykański doprowadził do apogeum dynamiczny proces zapoczątkowany reformami Leona: proces wyprowadzania katolicyzmu poza kontrreformację" - G. Weigel, Katolicyzm ewangeliczny, dz. cyt., s. 33, 60.

${ }^{17}$ Tamże, s. 10.

18 Tamże, s. 49. 
Kościoła (są one według Weigla upolitycznione i dotyczą jedynie spraw drugorzędnych ${ }^{19}$ i rozpocząć refleksję nad misyjna istotą Kościoła - refleksję dokonującą się w przestrzeni spraw absolutnie podstawowych ${ }^{20}$.

Z przekonania ojców soboru, że kwestią zasadniczą dla przyszłej egzystencji Kościoła i świata jest skoncentrowanie się na Chrystusie i jego Ewangelii, Weigel wyciaga następujący wniosek: ,podstawą katolicyzmu ewangelicznego jest przekonanie, że chrześcijaństwo jest religią objawioną"21, co oznacza, że jest ono dane przez Boga, aby „odczarowanemu”, a więc technokratycznemu światu, poprzez Pismo Święte i tradycję apostolską (które są centrum Kościoła), przekazać, że jesteśmy dziećmi Bożymi, przyjaciółmi Jezusa Chrystusa ${ }^{22}$. To twierdzenie, wielokrotnie podkreślane w Katolicyzmie ewangelicznym - może być uznane za kamień węgielny Weiglowskiego obrazu katolicyzmu i jego najważniejszy przymiot.

Weigel wyróżnia dziesięć podstawowych cech, które pozwalają opisać i wyróżnić katolicyzm ewangeliczny. Po pierwsze, jest on nade wszystko osobistą więzią, relacją wierzącego z Chrystusem. Spotkanie człowieka z żyjącym Bogiem jest pierwotne wobec wszelkich sposobów wyrazów wiary, norm z niej wypływających, wszelakich form kulturowych. Pozwala ono poznać prawdę o Bogu, człowieku i świecie. Pozwala doświadczyć zbawienia ${ }^{23}$. Ta relacja jest zbudowana na obrazie Jezusa, który wynika z Pisma Świętego, Tradycji i Urzędu Nauczycielskiego Kościoła. Jest ona bowiem częścią historii zbawienia, historii Boga działającego i objawiającego się ludzkim językiem w bosko-ludzkich dziełach. Uznanie, że jest się częścią tej historii, wymaga zrezygnowania $\mathrm{z}$ absolutyzowania własnego osądu, a przyjęcia autorytetu Tradycji ${ }^{24}$. Jest więc katolicyzm ewangeliczny skupiony na Biblii, która jest słowem Bożym, a więc nie tylko źródłem wiedzy o Bogu, ale formą Jego obecności w Kościele (jako taka jest koherentna z Tradycją Kościoła) i przestrzenią spotkania z Nim${ }^{25}$. Katolicyzm rozumiany jako nade wszystko relacja człowieka z Bogiem „celebruje siedem sakramentów jako dane przez Boga środki służące uświęceniu życia"26 i jest skoncentrowany na liturgii jako na sposobie budowania żywej więzi nie tylko jednostki z Bogiem, ale i całej wspólnoty. Sakramenty, a zwłaszcza Eucharystia, kształtują Kościół

\footnotetext{
19 Tamże, s. 151-158.

20 Tamże, s. 22.

21 Tamże, s. 52.

22 ,Jedynie to stanowi punkt wyjścia katolicyzmu ewangelicznego, jego głoszenia Dobrej Nowiny i reform, których się podejmie” - G. Weigel, Katolicyzm ewangeliczny, s. 55. „Zgodnie z tym rozumowaniem, katolicyzm ewangeliczny proponuje przyjaźń z Jezusem Chrystusem [...] jako odpowiedź na pytanie, którym jest każde ludzkie życie" - tamże, s. 61.

${ }^{23}$ G. Weigel, Katolicyzm ewangeliczny, dz. cyt., s. 91, 94n.

24 Tamżę, s. 97, 99.

${ }^{25}$ Tamże, s. 117-121.

26 Tamże, s. 102.
} 
i sprawiają, że staje się on coraz bardziej piękny, jak piękny jest Bóg, coraz bardziej podobny do $\mathrm{Niego}^{27}$. Jest on także hierarchiczny, uwypukla symfoniczną wielość misji w jednej, podstawowej misji głoszenia Ewangeliii ${ }^{28}$. Fakt, że katolicyzm ewangeliczny jest próbą budowania przyjaźni z Jezusem i zapraszania do niej wszystkich ludzi, sprawia, że jest on zarówno kontrkulturowy, jak i kulturotwórczy ${ }^{29}$, wypełnia bowiem swój obowiązek głoszenia Ewangelii ${ }^{30}$, wkraczając w sferę publiczną ${ }^{31}$ i wzywając do nawrócenia, które jest przecież nie tylko odrzuceniem zła, ale i budowaniem cywilizacji miłości ${ }^{32}$.

„Katolicyzm ewangeliczny to przede wszystkim wezwanie do nawrócenia”"33. Weigel proponuje nam swoje rozumienie katolicyzmu nie tylko po to, aby przedstawić, jak mógłby wyglądać idealny Kościół, ale także w tym celu, aby rozpocząć reformę wspólnoty, która istnieje już teraz. W drugiej części swojej książki pokazuje, jak mogłaby ona wyglądać. Opierając się na principiach katolicyzmu ewangelicznego, opisuje pożądaną reformę episkopatu, papiestwa, życia konsekrowanego, liturgii, życia intelektualnego, działalności polityczno-społecznej.

Podstawowe cechy katolicyzmu ewangelicznego pokazują wyraźnie, że Weigel, zapraszając do reformy Kościoła, nie chce odrzucić Tradycji i całego dziedzictwa Kościoła, by rozpocząć nową, wspaniałą erę katolicyzmu swojego pomysłu. Ważna jest dla niego ciągłość. Pisze: „Zachodzi istotowa ciagłość między tą nową formą katolicyzmu a jego początkami i rozwojem doktrynalnym, bo w przeciwnym nie byłaby to prawdziwie katolicka «forma» bytu Kościoła. [...] A może lepiej będzie powiedzieć, że jest to odkrycie i ponowne zastosowanie, w dwudziestopierwszowiecznej szacie, czegoś, co liczy już wiele lat i sięga pierwszych wieków chrześcijaństwa" ${ }^{34}$. Jeżeli istota katolicyzmu pozostaje ta sama, na czym więc polega świeżość - ewangeliczna świeżość tego, co proponuje?

Weigel próbuje pokazać oryginalność swojej propozycji, konfrontując ją $\mathrm{z}$,katolicyzmem kontrreformacyjnym” (używając jego terminologii). Jest to, według niego, ta forma przeżywania wiary chrześcijańskiej, która została zapoczątkowana reformami Soboru Trydenckiego. Jej korzenie tkwią w christianitas cywilizacji zbudowanej na/wewnątrz tradycji chrześcijańskiej, w której wiara, system społeczny, światopogląd stanowią jedną, spójną całość. Fundacyjnym doświadczeniem tej formy wyznawania wiary jest trauma reformacji, pęknięcie

\footnotetext{
${ }^{27}$ Warto tu zaznaczyć, że Weiglowi chodzi o liturgię sprawowaną zgodnie z wielowiekowymi tradycjami liturgicznymi Kościoła oraz o tę będącą autentyczną interpretacją nauczania Soboru Watykańskiego II. Por. G. Weigel, Katolicyzm ewangeliczny, dz. cyt., s. 113.

${ }^{28}$ G. Weigel, Katolicyzm ewangeliczny, dz. cyt., s. 121.

${ }^{29}$ Tamże, s. 126.

${ }^{30}$ Tamże, s. 133.

${ }^{31}$ Tamże, s. 129.

${ }^{32}$ Tamże, s. 106.

${ }^{33}$ Tamże, s. 162.

${ }^{34}$ Tamże, s. 18.
} 
tego świata powodowane próbą powrotu do jego źródeł - samej Ewangelii ${ }^{35}$. Jej cechami są: pełna podejrzliwości apologetyczna postawa wobec rzeczywistości, podkreślanie tych części Tradycji Kościoła, które przeciwstawiają się reformacji, budowanie specyficznie katolickiej kultury: katolickiej polityki, sztuki, wrażliwości, skoncentrowanie się na katechezie ${ }^{36}$.

Ten pobieżny opis katolicyzmu kontrreformacyjnego pokazuje, że według George'a Weigla był (jest) on skoncentrowany na sprawach drugorzędnych. Tak, był niesamowicie płodny. Jego owocem są nieprzeliczone wspaniałe pomniki kultury i rzesze świętych ludzi, którzy odnaleźli w nim drogę do Jezusa. Był on niewątpliwym sukcesem ${ }^{37}$. Jednakże $\mathrm{w}$ ferworze polemiki $\mathrm{z}$ innymi odłamami chrześcijaństwa - próbując odbudować christianitas, katolicyzm kontrreformacyjny zatracił żywotność i uniwersalność Ewangelii. Skutkiem tego ta forma funkcjonowania Kościoła przestała być adekwatna do warunków XX i XXI wieku. Dlaczego? Wbrew wszelkim wysiłkom katolicyzmu kontrreformacyjnego w naszych czasach dokonał się rozdział między kulturą a Ewangelią ${ }^{38}$. „Kościół dwudziestego pierwszego wieku na Zachodzie nie może dłużej liczyć na pomoc otaczającej go kultury w przekazie Ewangelii. Przeciwnie kultura dwudziestego pierwszego wieku jest zasadniczo wroga Ewangelii [...] Ludziom zaś trzeba proponować Ewangelię"39.

Atrakcyjność i świeżość katolicyzmu ewangelicznego polega zatem na tym, że jest on próbą powrotu do spraw pierwszorzędnych. Po okresie skupiania się na formach wyrazu istoty chrześcijaństwa (zawsze wtórnych wobec Ewangelii), a także po czasie, gdy były podejmowane próby zupełnie nowego określenia tego, czym są chrześcijaństwo i katolicyzm, jest on wezwaniem do skupienia się na tym, co najważniejsze; i dopiero w świetle tego, co najważniejsze, zinterpretowania na nowo różnych sposobów jego wyrazu. Weigel nie próbuje więc w kontrreformacyjny sposób bronić wszystkiego, co wypracował katolicyzm na przestrzeni dwóch tysięcy lat. Nie chce też tego ogromnego dziedzictwa odrzucać. Zaznacza, że zachowując właściwe proporcje, można na gruncie katolicyzmu spotkać się z żywym Bogiem.

Ta logika kontynuacji ma oczywiście swoje źródło - co jest oczywiste w myśli Jana Pawła II i Benedykta XVI. Już czytając opis katolicyzmu ewangelicznego, można zauważyć, że jest on sformułowaniem tego, co ci dwaj papieże nieustannie głosili, mówiąc o nowej ewangelizacji i prymacie Chrystusa.

${ }^{35}$ Tamże, s. 20.

${ }^{36}$ Tamże, s. 91n., 107, 113, 117, 124.

${ }^{37}$ Tamże, s. 34n, 113. Por. wywiad z George'em Weiglem przeprowadzony dla Katolickiej Agencji Informacyjnej 7 listopada 2014. http://ekai.pl/wydarzenia/swiat/x83632/zyjemy-w-chwilidecydujacej-dla-dziejow-kosciola/ [dostęp: 30.04.2015].

${ }^{38}$ G. Weigel, Katolicyzm ewangeliczny, dz. cyt., s. 29, 103.

39 Tamże, s. 10n. 
Jakkolwiek bowiem George Weigel upatruje prapoczątki dwudziestowiecznej odnowy Kościoła w działalności Leona XIII i uznaje Sobór Watykański II za jej źródło, to za twórców kształtu, który ta reforma powinna przyjąć, uważa ostatnich papieży - uczestników soboru. „Odnowa leonińska - pisze amerykański teolog - osiaggnąwszy swoje wypełnienie w Janie Pawle II i Benedykcie XVI, dziedzicach i autentycznych interpretatorach Drugiego Soboru Watykańskiego, zaprasza Kościół do Galilei, a nastepnie poza Galilee"

To właśnie Jan Paweł II od pierwszego dnia swojego pontyfikatu głosił to, co w roku 1983 nazwał „nową ewangelizacją”, a którą opisał w 1990 roku w encyklice Redemptoris missio ${ }^{41}$. To on wreszcie przygotował Wielki Jubileusz Roku 2000, który miał pobudzić ewangeliczny, misyjny zapał i w ten sposób wprowadzić Kościół w XXI wiek. Sednem zaś głoszonej Dobrej Nowiny miało być przeświadczenie, że można spotkać się z Chrystusem, a On może zbawić świat ${ }^{42}$.

Benedykt XVI zaś nie tylko kontynuował dzieło swojego poprzednika. Weigel zauważa, że ten pochodzący z Bawarii papież w twórczy sposób rozwinął ideę nowej ewangelizacji. Uczynił to poprzez podkreślanie (także stylem pełnienia swej posługi) prymatu Chrystusa i możliwości przeżycia osobistego z Nim spotkania $^{43}$. On także wielokrotnie podkreślał, że jedynie hermeneutyka reformy,

${ }^{40}$ Tamże, s. 136.

${ }^{41}$ Tamże, s. 7n.

${ }^{42}$ Tamże, s. 12, 26n.

${ }^{43}$ Jako że w wywiadzie udzielonym J.F. Desmond dla „National Catholic Register” G. Weigel wyraźnie wyraził te tezy, zostaje tu przytoczony dłuższy fragment tej rozmowy:

NCR: W książce Evangelical Catholicism stwierdza pan, że „przyjaźń z Jezusem Chrystusem” stanowi jeden z wielkich tematów pontyfikatu Benedykta XVI: „Kościół istnieje, by dać możliwość osobistej przyjaźni z Panem”. Jak i dlaczego papież Benedykt położył fundament dla takiego rozumienia misji Kościoła w świecie?

GW: Był to stały temat jego katechez i przepowiadania. Stanowi to odzwierciedlenie jego trwających wiele dziesiątków lat badań Nowego Testamentu i jego zorientowania na niemiecką teologię kerygmatyczną połowy XX wieku - jeden z nurtów refleksji teologicznej, które ukształtowały II Sobór Watykański. Dla Benedykta XVI centralnym dokumentem soborowym jest najprawdopodobniej Konstytucja dogmatyczna o Objawieniu Bożym Dei Verbum, w której ojcowie soborowi napisali, że prawda, jaką Bóg objawia o sobie i o nas najwyraźniej jaśnieje nam „w osobie Chrystusa, który jest zarazem pośrednikiem i pełnią całego objawienia".

NCR: Mówiąc o relacji między pontyfikatem papieża Benedykta i jego poprzednika, błogosławionego Jana Pawła II używa pan terminu „dynamiczna kontynuacja”. Inne określenie, jakie pan często stosuje do opisu powiązań tych dwóch pontyfikatów, to „strażnik”.

GW: Tak, to prawda, używa się określenia „strażnik”, choć często moim zdaniem jest ono nadużywane. Benedykt XVI kontynuował promocję „,nowej ewangelizacji” ogłoszonej przez Jana Pawła II i radykalniej skoncentrował ją na Chrystusie. Wysuwał także ważne osobiste propozycje: że piękno (zwłaszcza piękno liturgiczne) jest wyjątkowym oknem, otwierającym steranych postmodernistów na to, co prawdziwe i dobre; że demokracja zależy, w ostatecznym rozrachunku, od poszanowania „ekologii ludzkiej”, która jest wpisana w rzeczywistość; że Kościół, musi odkryć na nowo, jak odczytywać Biblię teologicznie, jeśli ma być ewangelicznym Kościołem misyjnym, ja- 
ciągłości zapewnia prawdziwą interpretację Ewangelii i nauczania Soboru Watykańskiego II ${ }^{44}$.

Krótko po wyborze Benedykta XVI na Stolicę Piotrową w 2005 roku George Weigel przedstawił listę spraw, którymi powinien zająć się nowo wybrany papież. Łudząco przypomina ona opis przestrzeni, które jako pierwsze muszą zostać odnowione przez katolicyzm ewangeliczny ${ }^{45}$.

George Weigel wpisuje w to dzieło nowej ewangelizacji, czyli także formowania katolicyzmu ewangelicznego, przesłanie papieża Franciszka. Wyraził to wprost w wywiadzie udzielonym Katolickiej Agencji Informacyjnej: „«Evangelii gaudium» to Franciszkowa wersja «Redemtoris missio» Jana Pawła II - wezwanie do Kościoła, by pozostawał w «ciagłej misji». Tym samym zakrojona na szeroką skalę strategia Franciszka jest zakrojoną na szeroką skalę strategią Jana Pawła II"46.

To właśnie interpretacja soboru, której dokonali Jan Paweł II i Benedykt XVI, pozwoliła na odrzucenie wszelkich prób dokonywania reformy katolicyzmu rozumianej jako próba zachowania wszystkich form katolicyzmu kontrreformacyjnego, jak i reformy rozumianej jako zerwanie z przeszłością ${ }^{47}$. W ten sposób pozwolili oni na wykrystalizowanie się wizji katolicyzmu ewangelicznego opisanego przez George'a Weigla.

Przyglądając się Weiglowskiej wizji katolicyzmu nowej ewangelizacji, można stwierdzić, że jej sednem jest Dobra Nowina o możliwości spotkania żywego Boga, którą trzeba głosić sposobami adekwatnymi dla XXI wieku, zachowując ciagłość Tradycji Kościoła.

Czy zatem na podstawie niniejszego opisu można powiedzieć, że katolicyzm proponowany przez George'a Weigla jest ewangeliczny? Z całą pewnością tak. Ewangelia Jezusa Chrystusa jest w jego centrum. Chrystus i spotkanie z Nim jest jego centrum.

kiego wymaga Sobór Watykański II i obecne warunki kulturowe. Tak więc te obydwa pontyfikaty należy rozumieć jako dwa ważne wydarzenia w jednej autorytatywnej interpretacji Soboru Watykańskiego II i zakończenie przejścia od katolicyzmu kontrreformacji (i jego nacisku na utrzymanie instytucjonalne) do katolicyzmu ewangelicznego, podkreślającego, że Kościół jest misją, do której swój wkład musi wnieść instytucja (i musi być ona zreformowana, aby to rzeczywiście nastapiło). Za: http://ekai.pl/wydarzenia/temat_dnia/x63941/swiat-i-kosciol-potrzebuja-swiadectwa/ [dostęp: 30.04.2015].

${ }^{44}$ Por. przemówienie Benedykta XVI dla pracowników Kurii Rzymskiej z dnia 22 grudnia 2005 roku, „L'Osservatore Romano” 2006, nr 2.

${ }^{45}$ Por. G. Weigel, Boży wybór, s. 295-363 oraz tegoż: Katolicyzm ewangeliczny, dz. cyt., s. $167-372$.

${ }^{46}$ G. Weigel, http://ekai.pl/wydarzenia/swiat/x83632/zyjemy-w-chwili-decydujacej-dla-dzie jow-kosciola/ [dostęp: 30.04.2015].

${ }^{47}$ G. Weigel, Katolicyzm ewangeliczny, dz. cyt., s. 33. 


\section{Ewangelikalność katolicyzmu}

Intrygującym jest pytanie, czy można przypisać Weiglowskiej koncepcji katolicyzmu pewne cechy ewangelikalności. Z pewnością można stwierdzić, że jest on ewangeliczny; jednak czy jest - chociażby w ograniczonym zakresie - ewangelikalny? Spróbujemy odpowiedzieć na to pytanie na podstawie pierwszej i drugiej części w tej pracy.

Stwierdziliśmy, że dla ewangelikalizmu fundamentalne jest przekonanie, że sednem chrześcijaństwa jest bezpośrednie, osobowe spotkanie człowieka z Bogiem. Bezsprzecznie można stwierdzić, że ta prawda leży również u podstaw idei katolicyzmu, którą przedstawił George Weigel. Spotkanie z Chrystusem - ożywiające, wszystko odnawiające - umieścił on w centrum swojej wizji. Tylko doświadczenie zbawienia pochodzącego od bliskiego ludziom Boga może sprawić, że wiara staje się czymś więcej niż kulturowe formy, wydarzeniem, które przemienia świat, które leży u podstaw kultur i jest ich zakwestionowaniem.

Jak już wskazano, kolejnym wyznacznikiem ewangelikalności jest przeżycie nawrócenia. Spotkanie z żywym Bogiem nie pozostawia ludzi takimi, jakim byli. Otrzymują oni wtedy nowe życie. Rodzą się na nowo. Muszą się nawrócić. Podobnie uważa Weigel. Według niego katolicyzm ewangeliczny to świadomy wybór Jezusa jako Zbawiciela. Spotkanie żywego Boga jest doświadczeniem miłości, która inspiruje do nawrócenia. Katolicyzm ewangeliczny jest głęboko nawrócony.

Tak jak nie można spotkać żywego Boga i się nie nawrócić, tak też nie można się nawrócić i nie odczuwać przymusu głoszenia Ewangelii - ta konstatacja jest kolejnym filarem światopoglądu ewangelikalnego, opisanego już w tej pracy. I znowu, jednym z rysów katolicyzmu nowej ewangelizacji jest jego misyjność: świadomość potrzeby opowiadania o Chrystusie i nieodparte pragnienie robienia tego.

Co więcej, Weiglowska wizja katolicyzmu jest wezwaniem do reformy życia kościelnego. To przekonanie jest jak najbardziej zgodne z ewangelikalnymi ideałami, które są per se wyraźnie reformacyjne. Nawrócenie nie jest prywatną sprawą. Nawracamy się we wspólnocie i jako wspólnota. Ba, jako wspólnota możemy i powinniśmy pomagać sobie nawzajem w powrocie do Boga i życiu Jego Ewangelią. Dlatego też z tego właśnie przekonania w ewangelikalizmie bierze się tak silne dążenie do ciągłej odnowy struktur i środków głoszenia Dobrej Nowiny. Weigel zauważa, że Kościół jest sakramentem. Jako taki powinien ciągle się odnawiać, reformować, aby wypełnić swoja misję ... głoszenia, że bliskie jest królestwo Boże: bliski jest Bóg, który wszystko odnawia. Każda litera Katolicyzmu ewangelicznego jest tego dowodem.

Sola Scriptura - dla ewangelików Pismo Święte ma rozstrzygający autorytet. Jest autentycznym i zupełnym objawieniem się Boga. Pismo Święte jest podstawowym źródłem, które zawiera słowo Boga, także dla katolicyzmu ewange- 
licznego. W tym punkcie jednak drogi katolicyzmu ewangelicznego i ruchu ewangelikalnego się rozchodzą. Weigel, budujący swój program reformy Kościoła oparty na zasadzie ciagłości, uznaje, że Biblia może być właściwie interpretowana wyłącznie w ramach żywej Tradycji Kościoła. Pismo Święte jest kwintesencją objawienia, które może być poprawnie odczytywane tylko w kontekście innych elementów tego dzieła Boga. I dopiero tak odczytywane jest fundamentem katolicyzmu nowej ewangelizacji.

Inne cechy charakterystyczne dla ewangelikalizmu, takie jak przekonanie o absolutnej suwerenności Boga, uznanie, że indywidualne oświecenie przez Ducha Świętego jest wystarczające do poprawnego zinterpretowania objawienia, czy też przekonanie, że ludzka natura jest całkowicie zepsuta, także nie mogą być wbudowane w ideową podstawę takiego katolicyzmu, który proponuje George

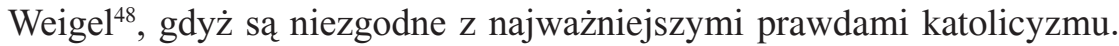

$\mathrm{Z}$ drugiej strony pewne konstytutywne elementy katolicyzmu ewangelicznego nie mogą być uznane za wspólne $\mathrm{z}$ ewangelikalną interpretacją chrześcijaństwa. Uznając Tradycję za część objawienia Bożego, Weigel przyjmuje, że ewangeliczne jest takie przeżywanie katolickiej tożsamości, które wyraża się w sakramentach, liturgii i widzialnej strukturze Kościoła.

Czy więc można powiedzieć, że wizja katolicyzmu zaproponowana przez George'a Weigla jest nie tylko ewangeliczna, ale i ewangelikalna? Takie stwierdzenie byłoby nadużyciem. Bezsprzecznie podstawowe założenia propozycji amerykańskiego teologa są zgodne z fundamentalnymi zasadami ewangelikalizmu, można więc stwierdzić, że Weiglowska propozycja ma pewne rysy ewangelikalne. Zawiera ona jednak cechy, które są zaprzeczeniem tego, czym jest ewangelikalizm (pewne założenia tego ruchu nie są możliwe do przyjęcia na gruncie teologii katolickiej), toteż nie można powiedzieć, że jest ona ewangelikalna czy też ewangelicka. Byłoby to semantycznym nadużyciem.

Dnia 1 maja 1994 roku George Weigel znalazł się w grupie ludzi, którzy zredagowali i podpisali dokument zatytułowany Evangelicals and Catholics together: The Christian Mission in the Third Millennium ${ }^{49}$. Dokument ten potwierdza, że Ewangelia Jezusa Chrystusa jest dramatycznie potrzebna światu, dlatego też trzeba ją głosić. Niestety, nie można tego robić skutecznie. Grzech podziału - grzech chrześcijan, a więc tych, którzy doświadczają zbawienia, zasłania Dawcę życia Tego, który z grzechu wyzwala. I dlatego tym bardziej nie można ustawać w wysiłkach poszukiwania jedności wszędzie tam, gdzie już teraz można ją znaleźćc ${ }^{50}$.

${ }^{48}$ Por. ciekawą interpretację podstaw doktryny katolickiej dokonaną przez G.R. Allisona w jego książce: Roman Catholic Theology and Practice. An Evangelical Asessment, Wheaton 2014. Publikacja ta kreśli także syntetyczny rys ewangelikalizmu, z którym warto się zapoznać.

${ }^{49} \mathrm{http} / / / w w w . f i r s t t h i n g s . c o m / a r t i c l e / 1994 / 05 /$ evangelicals--catholics-together-the-christian-mi ssion-in-the-third-millennium-2 [dostęp: 30.04.2015].

${ }^{50}$ Ten paradoks można zilustrować, przytaczając następujący obraz. W latach pięćdziesiątych 
W podobnym duchu wyraził się papież Franciszek, spotykając się w listopadzie 2014 roku z delegacją Aliansu Ewangelikalnego. Wyraźnie zaznaczył, iż ma nadzieję, że Duch Święty otworzy nowy rozdział w dialogu między Kościołem katolickim a wspólnotami należącymi do tego, najszybciej się rozprzestrzeniającego chrześcijańskiego ruchu. Wyraził przekonanie, że wszystkich chrześcijan łączy sakrament - doświadczenie zbawienia przez Boga, który jest blisko, którego spotykamy. Ono popycha tych, którzy go doświadczyli do głoszenia Ewangelii. Przeszkodą, aby czynić to skutecznie, są podziały między nimi ${ }^{51}$.

\section{Zakończenie}

W niniejszym studium podjęto próbę głębszego wyjaśnienia, w jaki sposób angielski termin evangelical jest rozumiany przez George'a Weigla. Celem tej analizy było zwrócenie uwagi na uniwersalność wizji katolicyzmu nowej ewangelizacji tego autora.

Stwierdzono, że podobnie jak angielskie evangelical może być przetłumaczone na polskie słowa: ewangeliczny, ewangelicki czy też ewangelikalny, tak i propozycja Weigla ma wiele wymiarów.

Oczywiście, zaproponowana przez niego idea katolicyzmu jest głęboko ewangeliczna. Ewangelia jest jej rdzeniem - lub wyrażając się ściślej: jej sercem. Sercem - gdyż sednem propozycji Weigla jest żywa Ewangelia: przemieniające spotkanie z żyjącym Jezusem Chrystusem. Dzięki temu ta wizja katolicyzmu jest krystalizacją chrystocentrycznego nauczania i posługi zarówno Jana Pawła II, jak i Benedykta XVI.

Jednocześnie można jej przypisać pewne cechy ewangelikalne. Żywa Ewangelia, która jest centrum ewangelikalizmu, jest też fundamentem Weiglowskiej propozycji. Ponadto ma ona inne cechy charakterystyczne dla tego ruchu; katolicyzm XXI wieku ma być według Weigla przeżyciem nawrócenia, które będzie inspirować reformę Kościoła i zaangażowane życie wiara.

Niewątpliwie więc katolicyzm widziany przez Weigla jest i ewangeliczny, i ma rysy ewangelikalne - czemu jednak ma służyć to podkreślanie podobieństw między pewną wizją przyszłości katolicyzmu i pewnym sposobem rozumienia

XX wieku Billy Graham, światowej sławy ewangelikalny kaznodzieja, wielokrotnie mówił, że nie jest możliwe, aby katolicy uczestniczyli w prowadzonych przez niego akcjach ewangelizacyjnych. Nie wyobrażał sobie, aby mógł ich zaprosić, czy też, że oni by jego zaproszenie przyjęli. Tenże sam protestancki lider przemawiał w 1978 roku na Jasnej Górze, a w roku 1981 spotkał się w Watykanie z papieżem Janem Pawłem II. Por. M.A. Noll, C. Nystrom, Is the Reformation over? An evangelical Assessment of contemporary Roman Catholicism, Grand Rapids 2005.

${ }^{51} \mathrm{http} / / / \mathrm{en}$. radiovaticana.va/news/2014/11/06/pope_francis_on_relations_between_catholics _and_evangelicals/1110330, a także: http://www.osservatoreromano.va/pl/news/gorace-serce-afryki [dostęp: 30.04.2015]. 
reformacji? Odpowiedź udzielona w tej pracy brzmi: pokazaniu uniwersalności i wszechstronności wizji George'a Weigla oraz - w szerszym kontekście - otwieraniu nowych, często zaskakujących płaszczyzn dialogu ekumenicznego. Kto szukałby ewangelikalnych inspiracji w twórczości autora powszechnie uznanego za żarliwego i prawowiernego katolika? Kto widziałby w dziele prefekta Kongregacji Nauki Wiary zwiastun nowej reformacji?

George Weigel udowodnił, że wizja katolicyzmu, wywodząca się z nauczania Jana Pawła II i Benedykta XVI, jest nie tylko głęboko ewangeliczna, ale ma także cechy ewangelikalne. Dzięki temu może służyć jako podstawa do poszukiwania chrześcijańskiej tożsamości w XXI wieku i przyczynek do głębszego dialogu między różnymi wspólnotami uczniów zmartwychwstałego Pana.

\section{The Hermeneutics of the Term Evangelical according to George Weigel's Evangelical Catholicism}

\section{Summary}

George Weigel, in his recent book Evangelical Catholicism, proposed a vision of the reform of the life of the Church. Because this Catholic theologian is widely known and respected, his book was translated into many languages and influenced the discussion about the shape of Catholicism in the $21^{\text {st }}$ century. It seems desirable to learn more about Weigel's proposal.

The article is an attempt to analyze Weigel's idea. In order to do so, we will try to scrutinize the full notion of the term evangelical, which describes the vision of Catholicism according to Weigel. For this reason the first section of the article contains a linguistic analysis of the different Polish equivalents of the English word: evangelical. The second section is a description of the vision of George Weigel. The third section answers the question if one can say that the vision of Catholicism by George Weigel has certain evangelical (that means: according to the basics of the Evangelical Movement) characteristics.

The conclusion of the analysis undertaken in the article is that the vision of Catholicism presented by George Weigel is not only compatible with the Gospel but resembles in certain aspects the ideas of Evangelicalism. As such it can be helpful in the fostering of ecumenical dialog.

\section{Keywords}

George Weigel, Evangelical Catholicism, evangelicalism, reform of the Church

\section{Słowa kluczowe}

George Weigel, katolicyzm ewangeliczny, ewangelikalność, reforma Kościoła

\section{Bibliografia}

Allison'a G.R., Roman Catholic Theology and Practice. An Evangelical Assessment, Wheaton 2014.

Balmer R., Encyclopedia of Evangelicalism, Waco 2004. 
Elektroniczna encyklopedia i stownik ortograficzny PWN, Warszawa 2002.

Evangelical Dictionary of Theology, red. W. A. Elwell, Grand Rapids 2001.

George T., The Promise of Benedict XVI, w: Christianity Today, 6 (46) 2005.

http://en.radiovaticana.va/news/2014/11/06/pope_francis_on_relations_between_catholics _and_evangelicals/1110330

http://www.ewst.pl/centrum-edukacyjne/ewangelikalizm/ [dostęp: 30.04.2015].

http://www.osservatoreromano.va/pl/news/gorace-serce-afryki [dostęp: 30.04.2015].

McGrath A., Evangelicalism and the Future of Christianity, London-Sydney 1994.

Noll M. A., Nystrom C., Is the Reformation over? An evangelical Assessment of contemporary Roman Catholicism, Grand Rapids, 2005.

Oxford Dictionary of English, red. C. Soanes, Kindle edition, 2010.

Przemówienie Benedykta XVI dla pracowników Kurii Rzymskiej, w: http://www.fronda.pl /blogi/drogi-i-bezdroza/benedykt-xvi-o-poprawnym-interpretowaniu-soboru,38816.html

The New Oxford American Dictionary, red. A. Stevenson, Ch.A. Lindberg, Kindle edition 2008.

Weigel G., Boży Wybór, Kraków 2006.

Weigel G., Evangelical Catholicism: Deep Reform in the 21 st-Century Church, New York 2014.

Weigel G., Evangelicals and Catholics together. The Christian mission in the third millenium Ehttp://www.firstthings.com/article/1994/05/evangelicals--catholics-together-thechristian-mission-in-the-third-millennium-2 [dostęp: 30.04.2015].

Weigel G., Świat i Kościót potrzebuja świadectwa, w: http://ekai.pl/wydarzenia/temat_dn ia/x63941/swiat-i-kosciol-potrzebuja-swiadectwa/ [dostęp: 30.04.2015].

Weigel G., Żyjemy w chwili decydujacej dla dziejów Kościoła, w: http://ekai.pl/wydarzenia/swiat/x83632/zyjemy-w-chwili-decydujacej-dla-dziejow-kosciola/ [dostęp: 30.04.2015].

Wielki słownik angielsko-polski, red. J. Linde-Usiekniewicz, Warszawa 2004.

Wielki stownik języka polskiego Instytutu Języka Polskiego PAN, red. P. Żmijgrodzki, wersja elektroniczna: http://wsjp.pl/, stan z 30. Kwietnia 2015.

Zieliński T., Protestantyzm ewangelikalny. Studium specyfiki religijnej, Katowice 2014. 